\title{
Microanalysis of fluid inclusions in crustal hydrothermal systems using laser ablation methods
}

\section{Journal Article}

Author(s):

Wagner, Thomas; Fusswinkel, Tobias; Wälle, Markus; Heinrich, Christoph A. (D)

Publication date:

2016-10-01

Permanent link:

https://doi.org/10.3929/ethz-b-000121889

Rights / license:

In Copyright - Non-Commercial Use Permitted

Originally published in:

Elements 12(5), https://doi.org/10.2113/gselements.12.5.323

Funding acknowledgement:

146651 - Mineral resources: Physical dynamics driving chemical enrichment of rare metals (SNF) 
This is the Green Open Access version of the paper originally published by Elements, v. 12, p. 323-328, made available by research collection.ethz.ch

\title{
Laser-ablation microanalysis of fluid inclusions in crustal hydrothermal systems
}

\author{
Thomas Wagner ${ }^{1}$, Tobias Fusswinkel ${ }^{1}$, Markus Wälle² \\ Christoph A. Heinrich ${ }^{2}$
}

\footnotetext{
${ }^{1}$ Department of Geosciences and Geography, Division of Geology and Geochemistry, University of Helsinki, Gustaf Hällströmin katu 2a, FI-00014 Helsinki, Finland (E-mail: thomas.wagner@helsinki.fi; tobias.fusswinkel@helsinki.fi)

${ }^{2}$ ETH Zurich, Department of Earth Sciences, Institute of Geochemistry and Petrology, Clausiusstrasse 25, 8092 Zurich, Switzerland (E-mail: markus.waelle@erdw.ethz.ch; christoph.heinrich@erdw.ethz.ch)
}

Revised version R2 submitted to: Elements

Date: 7 July 2016 


\section{ABSTRACT}

2 Quantitative analysis of microscopic fluid inclusions has greatly improved our understanding

3 of fluid-rock interaction and ore deposit formation. Spatially resolved analyses track the

4 chemical evolution of distinct fluids, within texturally complex veins and along extensive

5 fluid pathways. Chemical (e.g., $\mathrm{Br} / \mathrm{Cl}$ ) and isotopic tracers (e.g., Pb) identify sources of fluids

6 and timescales of transient fluid flow. Selectively metal-enriched fluids, compared to normal

7 rock-buffered fluids, control the formation of major magmatic-hydrothermal and sediment-

8 hosted ore deposits. Besides chloride as dominant anion of crustal fluids, sulfur decisively

9 influences the partitioning, transport and precipitation of ore metals by single-phase and twophase fluids of sedimentary, metamorphic and magmatic origin.

KEYWORDS: Fluid inclusions, metamorphic fluids, ore fluids, fluid-rock equilibria, ore metals, 13 sulfur

\section{INTRODUCTION}

Aqueous fluids play a key role in mass transfer processes in the Earth, including the generation of magmas in the Earth's mantle above subduction zones, the release of fluids from crystallizing magmas, the production and migration of fluids during mountain building, the formation of hydrothermal metal ore deposits and the interaction of fluids released from the deep Earth with the hydrosphere and atmosphere. As only the topmost part of the Earth's crust is accessible to direct sampling of fluids, e.g., discharge from geothermal systems and deep drillholes, most of the information we have about the compositions of deep Earth fluids comes from studies of paleofluids that are preserved as fluid inclusions in minerals.

Chemical analysis of the solute content (dissolved cations, anions and volatiles) of fluid inclusions historically involved bulk extraction of numerous fluid inclusions followed by analysis of leachates by ion chromatography and conventional solution chemistry. Such 
averaged data from potentially different inclusion generations in one sample provide little information about the time-space evolution of fluid-rock systems. Therefore, methods were developed for performing quantitative multi-element analysis of single fluid inclusions in textural context. Laser-ablation inductively-coupled plasma-mass spectrometry (LA-ICP-MS) has become the most widely used method for multi-element analysis, because of its efficiency, its high sensitivity and the possibilities for multi-element quantification (Heinrich et al. 2003; Pettke et al. 2012 and references therein).

\section{FLUID INCLUSION MICROANALYSIS BY LA-ICP-MS}

Fluid inclusion microanalysis using LA-ICP-MS has developed from early work that targeted ore metal concentrations in hydrothermal mineral deposits (Audétat et al. 1998; Ulrich et al. 1999) to multi-elemental analysis of a wide range of crustal fluids that include igneous, metamorphic and sedimentary environments (Scambelluri et al. 2004; Samson et al. 2008; Wilkinson et al. 2009; Kouzmanov and Pokrovski 2012; Marsala et al. 2013; Sirbescu et al. 2013). LA-ICP-MS analysis is comparatively fast and inexpensive, once dedicated instrumentation is established, thus allowing compositional reconstruction of the time sequence of fluid inclusion assemblages from texturally well-constrained samples (growthzoned crystals, sets of crosscutting veins and fractures). Highly sensitive mass spectrometers now enable multi-element analysis of moderate sized fluid inclusions (20 to $50 \mu \mathrm{m}$, depending on elemental concentration and salinity), comprising major rock-forming elements, ore metals, S, B and the halogens (Seo et al. 2011). Controlled ablation of diverse host minerals including quartz or infrared-light transparent pyrite requires short UV wavelengths, and $193 \mathrm{~nm}$ Excimer lasers are used in most successful fluid inclusion labs today (Kouzmanov and Pokrovski 2012; Pettke et al. 2012). Recent progress has included the analysis of anions such as $\mathrm{S}, \mathrm{Cl}$ and $\mathrm{Br}$ (Seo et al. 2011; Hammerli et al. 2013), and precise quantification of $\mathrm{Pb}$ and $\mathrm{Sr}$ isotope compositions from single fluid inclusions using multi- 
collector ICP-MS (Pettke et al. 2010, 2012). The combination of different mass spectrometers opens up exciting possibilities for simultaneously tracing the source of metals and the source of fluid salinity in crustal fluid systems and to quantitatively address processes of fluid-rock reaction.

Absolute quantification of elemental concentrations in fluid inclusions is based on models that use $\mathrm{Na}$ concentration as the internal standard, which is obtained from the interpretation of fluid inclusion freezing experiments in terms of binary and ternary water-salt systems. The accuracy of correction methods has been tested against synthetic fluid inclusions (Allan et al. 2005), but the approach requires correction for more complex natural geofluids containing high concentrations of dissolved gases and salts other than $\mathrm{NaCl}$.

Despite analytical progress, the short and highly transient signals from fluid inclusions still pose major challenges for single-collector mass-spectrometric analysis and data quantification. Analysis of numerous inclusions from a petrographically well-defined fluid inclusion assemblage is essential to average signal fluctuations, to assess the significance of element concentrations for each element, and to estimate the real chemical variability of each fluid represented by one fluid inclusion assemblage (Heinrich et al. 2003). Quadrupole and sector-field ICP-MS instruments (Wälle and Heinrich 2014) measure different masses (elements) sequentially by rapid scanning, requiring a trade-off between accurate characterization of transient signals (detection limit, representative quantification) and the number of recorded elements (typically 10-25). Sequential measurement of multiple elements in a short transient signal from a fluid inclusion can lead to non-representative sampling (Pettke et al. 2012), which is the main cause of random errors of 10-30\% when analyzing multiple inclusions in a fluid inclusion assemblage with consistent microthermometric properties (Heinrich et al. 2003). Non-representative sampling of transient signals may even lead to a systematic bias in concentration results (Rauchenstein-Martinek et al. 2014). Recent improvements in time-of-flight (TOF) ICP-MS instrumentation may overcome this limitation, 
because this detection method simultaneously records the entire mass spectrum with a repeat rate that is at least 1000 times faster than in typical quadrupole ICP-MS analysis (FIG. 1). This novel technique has great potential for the next level of fluid inclusion microanalysis (Harlaux et al. 2015), particularly if applied to small inclusions in combination with laser sampling cells with shorter wash-out times.

\section{CHEMISTRY OF METAMORPHIC FLUIDS}

The bulk compositions of metamorphic fluids in orogenic belts and subduction zones have been studied by conventional microthermometry and Raman spectroscopy, but few studies have used LA-ICP-MS analysis to determine the elemental compositions of metamorphic fluids (Scambelluri et al. 2004; Marsala et al. 2013; Rauchenstein-Martinek et al. 2014). Classical fluid inclusion studies demonstrate that the fluid composition changes in a systematic way along a prograde Barrovian sequence from subgreenschist- to amphibolitefacies, with consecutive fluid zones characterized by predominance of heavier hydrocarbons, methane, water and carbon dioxide. The fluid inclusion data support the generally accepted model of progressive devolatilization driven by increasing temperature and pressure along a prograde metamorphic sequence.

Recent studies from the Alpine and Hercynian orogenic belts (Marsala et al. 2013; Rauchenstein-Martinek et al. 2014) showed that in rock-buffered low- to moderate-salinity (1 to 10 wt.\% $\mathrm{NaCl}$ equivalent) aqueous to aqueous-carbonic fluids, $\mathrm{Na}, \mathrm{K}$ and $\mathrm{Ca}$ are the dominant cations, whereas the concentrations of other alkali and alkaline-earth metals $(\mathrm{Li}, \mathrm{Rb}$, $\mathrm{Cs}, \mathrm{Mg}, \mathrm{Sr}$ and $\mathrm{Ba}$ ) are much lower, typically on the order of a few ppm. The concentrations of the alkali and alkaline-earth metals correlate with bulk salinity, consistent with the general trend of rock-buffering in a wide range of geological environments (Yardley 2005). B, As and $\mathrm{Sb}$ are characteristic elements of metamorphic fluids (Scambelluri et al. 2004; Marsala et al. 2013). The concentrations of boron vary in a rather narrow range between 200 and $1500 \mathrm{ppm}$ 
105 (FIG. 2), suggesting that B is rock-buffered by minerals such as tourmaline or B-bearing 106 muscovite. The concentrations of the base metals $\mathrm{Cu}, \mathrm{Zn}$ and $\mathrm{Pb}$ are on the order of 1-10 ppm, which contrasts with the much higher concentrations (several 100 to $1000 \mathrm{ppm}$ ) in basin- and basement-hosted fluid systems that are linked to sediment-hosted $\mathrm{Pb}-\mathrm{Zn}$ and $\mathrm{Cu}$ ore deposits (Wilkinson et al. 2009). Typical low-salinity metamorphic fluids are therefore unlikely candidates for forming major base metal ore deposits.

Sulfur concentrations increase systematically along a prograde sequence through the Central Alps, from 100-300 ppm in veins hosted by subgreenschist- and lower greenschistgrade rocks, up to $3500 \mathrm{ppm}$ in veins in amphibolite-grade rocks. This increase reflects progressive desulfidation of the host rocks along with prograde dehydration and decarbonation, producing S-rich aqueous-carbonic fluids at amphibolite-grade conditions (Rauchenstein-Martinek et al. 2014). Thermodynamic modeling of fluid-mineral equilibria demonstrates that the measured S concentrations are in agreement with saturation of pyrite (FIG. 3A). The measured Au concentrations are very low, on the order of 3 to $30 \mathrm{ppb}$, and are one to three orders of magnitude lower than the Au solubility calculated assuming saturation of metallic $\mathrm{Au}$ (FIG. 3B). These results suggest that metamorphic fluids produced by devolatilization along a prograde sequence are normally undersaturated in Au, and their Autransporting potential is not limited by solubility but rather by Au availability in the source rocks. Typical metamorphic fluids produced from devolatilization of metasediments, metagranitoids and mafic schists have therefore only moderate potential for forming major orogenic gold deposits, unless extreme degrees of fluid focusing and highly efficient precipitation are invoked. World-class orogenic gold deposits more likely form when metamorphic fluids are produced from specialized source rocks that are pre-enriched in gold, or when metamorphic fluid systems experience an input of Au-rich magmatic fluids. This conclusion is consistent with the first experimental study that combined synthetic fluid 
inclusions with LA-ICP-MS microanalysis, to demonstrate very high Au solubility at hightemperature metamorphic conditions (Loucks and Mavrogenes 1999).

\section{MAGMATIC-HYDROTHERMAL FLUIDS}

Magmatic-hydrothermal ore fluids were the first target of research after successful development of LA-ICP-MS for microanalysis of fluid inclusions. LA-ICP-MS analysis has been particularly influential in elucidating magmatic-hydrothermal processes because of the textural complexities of natural samples, which commonly record a time sequence of multiple fluid pulses with variable fluid compositions and fluid phase states. In particular, the evolution of single-phase 'supercritical' fluids in magma chambers separating into two phases of coexisting saline liquid and lower-density vapor on ascent to hydrothermal ore deposits can lead to large variations in elemental composition of magmatic fluids. Careful petrography of successively trapped inclusion assemblages followed by LA-ICP-MS analysis identified fluid mixing as a major factor driving ore mineral precipitation in cassiterite-tourmaline veins (Audétat et al. 1998). A rapid decrease in $\mathrm{Cu}$ concentrations in brine inclusions has shown that $\mathrm{Cu}$ is deposited from vapor-dominated two-phase fluids in porphyry $\mathrm{Cu}$ - $\mathrm{Au}$ deposits over a small temperature interval. In combination with cathodoluminescence imaging of vein textures, similar results from several porphyry deposits showed that economic mineralization occurred at rather low temperature, after the precipitation of quartz in the prominent stockwork veins in such deposits.

The discovery of high concentrations of selected elements in magmatic-hydrothermal vapor inclusions (e.g., $\mathrm{Cu}, \mathrm{Au}, \mathrm{As}, \mathrm{B}$; Audétat et al. 1998) triggered experimental research into metal solubility in low-density fluids at high temperature (Migdisov et al. 1999; Pokrovski et al. 2008; Zajacz et al. 2010). It also motivated instrumental improvements for the analysis of anions by LA-ICP-MS (Seo et al. 2011). The detection of high S concentrations in magmatic vapor inclusions support the interpretation that sulfide is the 
dominant complexing agent driving the selective transfer of $\mathrm{Au}$ from saline brine to lowsalinity vapor, but it also identified $\mathrm{S}$ as the chemical driver for selective ingress of $\mathrm{Cu}$ into $\mathrm{S}$ rich vapor inclusions after fluid entrapment in quartz (Lerchbaumer and Audétat 2012).

Physical separation of vapor from brine in the proximal magmatic-hydrothermal domain of miarolitic cavities and porphyry deposits leads to a chemical divide between different evolution paths taken by fluids during cooling from magmatic to normal uppercrustal temperatures. Magmatic vapor expansion leads to wholesale co-precipitation of metals in high-grade porphyry-Cu-Mo-Au deposits, probably accompanied by saturation of solid halite. Alternatively, the vapor phase can cool at depth and contract in the single-phase stability field towards a S-, As- and Au-enriched, but Fe- and base-metal depleted low-salinity aqueous liquid (Heinrich et al. 2004). Such fluids are the optimal transport medium for $\mathrm{Au}$ from a hydrous magma to high-grade epithermal ore deposits, where Au is precipitated either in reduced sedimentary host rocks (Carlin-type deposits) or in high- to intermediatesulfidation precious-metal veins (Márquez-Zavalía and Heinrich 2016; FIG. 4). The Fe-rich magmatic-hydrothermal brine, on the other hand, becomes progressively depleted in sulfide by precipitation of pyrite during cooling, leading to residual brines with anomalously high $\mathrm{Pb}$, $\mathrm{Zn}$ and possibly $\mathrm{Cu}$ concentrations (FIG. 5). Such brines may be mobilized by later fluid convection, e.g., if evaporitic brines of sufficient density displace and mix with deep-seated post-magmatic brine, potentially generating sulfide-depleted ore fluids for efficient formation of sediment-hosted base metal deposits.

\section{BASIN-BASEMENT INTERACTION IN ORE FORMATION}

Chloride-rich metal-bearing aqueous fluids are responsible for the formation of a wide range of hydrothermal ore deposit types, including sediment-hosted low-temperature $\mathrm{Pb}-\mathrm{Zn}, \mathrm{Cu}$ and U deposits (Wilkinson et al. 2009; Richard et al. 2012). Unconformities between sedimentary basins and the underlying basement and crustal-scale fault zones extending into the basement 
exert first-order structural controls on mineralization. They are the locations where deepsourced S-depleted and metal-rich saline fluids derived from the basement are injected into the sedimentary units. Mixing of these metal-loaded fluids with formation waters that are rich in reduced $\mathrm{S}$ then drives efficient ore precipitation (Wilkinson et al. 2009). Combined LAICP-MS analysis of metal concentrations and halogen ratios $(\mathrm{Br} / \mathrm{Cl})$ in fluid inclusions provides new insight into the dynamics of fluid mixing processes, by revealing evidence for mixing at the scale of individual quartz growth zones from unconformity-related $\mathrm{Pb}-\mathrm{Zn}$ veins. Accounting for fault hydrology and likely timescales required for fluid mixing, this feature can only be explained by fast upward flow of chemically distinct fluids drained from different levels of the crystalline basement (Bons et al. 2014). This process model provides a distinct alternative to classical scenarios where interaction of different fluid systems takes place at the basement-cover interface.

Further insight into the ultimate source of ore fluids in sediment-hosted $\mathrm{Pb}-\mathrm{Zn}, \mathrm{Cu}$ and $\mathrm{U}$ deposits can be gained from comparing their ore metal concentrations with those of typical rock-buffered crustal fluids (FIG. 5). The concentrations of $\mathrm{Pb}$ and $\mathrm{Zn}$ in rock-buffered fluids from geothermal systems and sedimentary formations define a broad trend that correlates positively with temperature and fluid salinity (Yardley 2005). By contrast, the ore stage fluids of unconformity related deposits plot distinctively above this trend, and their metal concentrations have been described as anomalously high (Wilkinson et al. 2009). These data include the exceptionally high $\mathrm{Pb}$ (and reconstructed $\mathrm{Zn}$ ) concentrations of sphalerite-hosted fluid inclusions from the $\mathrm{Pb}-\mathrm{Zn}$ deposits of the Irish Midlands Basin (Wilkinson et al. 2009). Even more extreme base metal concentrations have been found in fluid inclusions from unconformity-related U deposits (Richard et al. 2012), probably reflecting their highly oxidized and low $\mathrm{pH}$ character sustaining high base metal solubility. The most metal-poor fluids from subeconomic basement-hosted $\mathrm{Pb}-\mathrm{Zn}$ veins in the Schwarzwald area, with low $\mathrm{Br} / \mathrm{Cl}$ ratios fingerprinting them as sedimentary formation waters derived from halite 
dissolution, mostly plot on the rock-buffered trend (FIG. 5). By contrast, the most metal-rich fluids with the highest $\mathrm{Br} / \mathrm{Cl}$ ratios are above the rock-buffered trend. Despite the large and systematic variation in absolute base-metal concentrations and in $\mathrm{Br} / \mathrm{Cl}$, the ratio of $\mathrm{Pb} / \mathrm{Zn}$ of fluids from a wide range of geological environments are remarkably constant (FIG. 6). This suggests that base metal ratios and their concentrations are largely solubility-controlled through temperature-dependent equilibria between fluid and sulfide minerals (Yardley 2005), but with different factors controlling redox conditions and S speciation. Therefore, the metaltransporting ore fluids of sediment-hosted $\mathrm{Pb}-\mathrm{Zn}, \mathrm{Cu}$ and $\mathrm{U}$ deposits are only anomalous for the inferred temperatures of fluid entrapment and ore deposition (FIG. 5). Their metal concentrations and $\mathrm{Pb} / \mathrm{Zn}$ ratios are consistent with rock-buffered fluids derived from reservoirs at greater depths and higher temperatures. Tectonically controlled, highly transient episodes of focused fluid flow are able to transfer large volumes of such hot metal-rich fluids from deep reservoirs to the basement-cover interface and drive the formation of major unconformity-related ore deposits.

\section{FUTURE WORK}

Despite major progress in our ability to analyze fluid inclusions with LA-ICP-MS during the past decade, there still remains much work to be done to fill the large gaps in our knowledge of the composition of paleofluids in a wide range of geological environments. A major challenge is the analysis of small fluid inclusions (below $10 \mu \mathrm{m}$ ) with low total dissolved solute content, which are ubiquitous in many igneous, metamorphic and sedimentary rocks and important types of world-class hydrothermal ore deposits. More sensitive ICP-MS instruments that facilitate better time resolution and simultaneous analysis of many elements (Harlaux et al. 2015) have great potential to overcome the current analytical limitations. Then it may become possible to obtain multi-element fluid inclusion data from eclogite- and 
granulite-facies metamorphic rocks, as well as from poorly understood but globally important ore deposits such as iron-oxide-copper-gold deposits and Carlin-type gold deposits. Another major challenge concerns the reliable and accurate quantification of LA-ICPMS fluid inclusion data. Progress in quantification of complex geofluids requires a combination of LA-ICP-MS analysis with additional microthermometric, Raman (Sirbescu et al. 2013) or FTIR spectroscopic measurements, and integration with better thermodynamic models for interpreting microthermometric data (Leisen et al. 2012) based on accurate experimental studies of phase equilibria.

Finally, trapping synthetic inclusions of fluids and melts during experiments at high pressures and temperatures offers new and still expanding methods in experimental geochemistry. With different inert trapping phases including quartz, corundum or diamond, studies of fluid-melt partitioning and mineral solubility (e.g., Loucks and Mavrogenes 1999; Zajacz et al. 2010; Zhang et al. 2012) can be extended from crustal conditions to those of the upper mantle (Spandler et al. 2007). LA-ICP-MS microanalysis thus provides access to understanding the trace element geochemistry of unquencheable phases at extreme conditions of the Earths interior.

\section{ACKNOWLEDGEMENTS}

Funding for this research was provided by the Academy of Finland (project number 266180 to TW) and the Swiss National Science Foundation (grant numbers 200021-130202 to TW and 200021-146651 to $\mathrm{CH})$. 
REFERENCES

257

258

259

260

261

262

263

264

265

266

267

268

269

270

271

272

273

274

275

276

277

278

279

280

Allan MM, Yardley BWD, Forbes LJ, Shmulovich KI, Banks DA, Shepherd TJ (2005) Validation of LA-ICP-MS fluid inclusion analysis with synthetic fluid inclusions. American Mineralogist 90: 1767-1775

Audétat A, Günther D, Heinrich CA (1998) Formation of a magmatic-hydrothermal ore deposit: Insights with LA-ICP- MS analysis of fluid inclusions. Science 279: 20912094

Bons PB, Fusswinkel T, Gomez-Rivas E, Markl G, Wagner T, Walter B (2014) Fluid mixing from below in unconformity-related hydrothermal ore deposits. Geology 42: $1035-$ 1038

Hammerli J, Rusk B, Spandler C, Emsbo P, Oliver NHS (2013) In situ quantification of Br and $\mathrm{Cl}$ in minerals and fluid inclusions by LA-ICP-MS: A powerful tool to identify fluid sources. Chemical Geology 337: 75-87

Harlaux M, Borovinskaya O, Frick DA, Tabersky D, Gschwind S, Richard A, Günther D, Mercadier J (2015) Capabilities of sequential and quasi-simultaneous LA-ICPMS for the multi-element analysis of small quantity of liquids ( $\mathrm{pl}$ to $\mathrm{nl}$ ): Insights from fluid inclusion analysis. Journal of Analytical Atomic Spectrometry 30: 1945-1969

Heinrich CA, Pettke T, Halter WE, Aigner-Torres M, Audétat A, Günther D, Hattendorf B, Bleiner D, Guillong M, Horn I (2003) Quantitative multi-element analysis of minerals, fluid and melt inclusions by laser-ablation inductively-coupled-plasma massspectrometry. Geochimica et Cosmochimica Acta 67: 3473-3497

Heinrich CA, Driesner T, Stefánsson A, Seward TM (2004) Magmatic vapor contraction and the transport of gold from the porphyry environment to epithermal ore deposits. Geology 32: 761-764 
Kouzmanov K, Pokrovski GS (2012) Hydrothermal controls on metal distribution in porphyry $\mathrm{Cu}(-\mathrm{Mo}-\mathrm{Au})$ systems. Society of Economic Geologists Special Publications 16: 573618

Leisen M, Dubessy J, Boiron MC, Lach P (2012) Improvement of the determination of element concentrations in quartz-hosted fluid inclusions by LA-ICP-MS and Pitzer thermodynamic modeling of ice melting temperature. Geochimica et Cosmochimica Acta 90: 110-125

Lerchbaumer L, Audétat A (2012) High Cu concentrations in vapor-type fluid inclusions: An artifact? Geochimica et Cosmochimica Acta 88: 255-274

Loucks RR, Mavrogenes JA (1999) Gold solubility in supercritical hydrothermal brines measured in synthetic fluid inclusions. Science 284: 2159-2163

Márquez-Zavalía F, Heinrich CA (2016) Low-salinity magmatic fluids in a volcanic-hosted epithermal carbonate - base-metal - gold vein system: Alto de la Blenda, Farallón Negro, Argentina. Mineralium Deposita DOI 10.1007/s00126-016-0639-y

Marsala A, Wagner T, Wälle M (2013) Late-metamorphic veins record deep ingression of meteoric water: a LA-ICPMS fluid inclusion study from the fold-and-thrust belt of the Rhenish Massif, Germany. Chemical Geology 351: 134-153

Migdisov AA, Williams-Jones AE, Suleimenov OM (1999) Solubility of chlorargyrite (AgCl) in water vapor at elevated temperatures and pressures. Geochimica et Cosmochimica Acta $63: 3817-3827$

Pettke T, Oberli F, Heinrich CA (2010) The magma and metal source of giant porphyry-type ore deposits, based on lead isotope microanalysis of individual fluid inclusions. Earth and Planetary Science Letters 296: 267-277

Pettke T, Oberli F, Audétat A, Guillong M, Simon AC, Hanley JJ, Klemm LM (2012) Recent developments in element concentration and isotope ratio analysis of individual fluid 
inclusions by laser ablation single and multiple collector ICP-MS. Ore Geology Reviews 44: 10-38

Pokrovski GS, Borisova AY, Harrichoury JC (2008) The effect of sulfur on vapor-liquid fractionation of metals in hydrothermal systems. Earth and Planetary Science Letters 266: $345-362$

Rauchenstein-Martinek K, Wagner T, Wälle M, Heinrich CA (2014) Gold concentrations in metamorphic fluids: a LA-ICPMS study of fluid inclusions from the Alpine orogenic belt. Chemical Geology 385: 70-83

Richard A, Rozsypal C, Mercadier J, Banks DA, Cuney M, Boiron MC, Cathelineau M (2012) Giant uranium deposits formed from exceptionally uranium-rich acidic brines. Nature Geoscience 5: 142-146

Samson IM, Williams-Jones AE, Ault KM, Gagnon JE, Fryer BJ (2008) Source of fluids forming distal $\mathrm{Zn}-\mathrm{Pb}-\mathrm{Ag}$ skarns: Evidence from laser ablation-inductively coupled plasma-mass spectrometry analysis of fluid inclusions from El Mochito, Honduras. Geology 36: 947-950

Scambelluri M, Müntener O, Ottolini L, Pettke T, Vannucci R (2004) The fate of B, Cl and Li in the subducted oceanic mantle and in the antigorite breakdown fluids. Earth and Planetary Science Letters 222: 217-234

Seo JH, Guillong M, Aerts M, Zajacz Z, Heinrich CA (2011) Microanalysis of S, Cl, and Br in fluid inclusions by LA-ICP-MS. Chemical Geology 284: 35-44

Sirbescu MLC, Krukowski EG, Schmidt C, Thomas R, Samson IM, Bodnar RJ (2013) Analysis of boron in fluid inclusions by microthermometry, laser ablation ICP-MS, and Raman spectroscopy: Application to the Cryo-Genie pegmatite, San Diego County, California, USA. Chemical Geology 342: 138-150 
Spandler C, Mavrogenes J, Hermann J (2007) Experimental constraints on element mobility from subducted sediments using high-P synthetic fluid/melt melt inclusions. Chemical Geology 239: 228-249

Ulrich T, Günther D, Heinrich CA (1999) Gold concentrations of magmatic brines and the metal budget of porphyry copper deposits. Nature 399: 676-679

Wälle M, Heinrich CA (2014) Fluid inclusion measurements by laser ablation sector-field ICP-MS. Journal of Analytical Atomic Spectrometry 29: 1052-1057

Wilkinson JJ, Stoffell B, Wilkinson CC, Jeffries TE, Appold MS (2009) Anomalously metalrich fluids form hydrothermal ore deposits. Science 323: 764-767

Yardley BWD (2005) Metal concentrations in crustal fluids and their relationship to ore formation. Economic Geology 100: 613-632

Zajacz Z, Seo JH, Candela PA, Piccoli PM, Heinrich CA, Guillong M (2010) Alkali metals control the release of gold from volatile-rich magmas. Earth and Planetary Science Letters 297: 50-56

Zhang L, Audétat A, Dolejs D (2012) Solubility of molybdenite $\left(\mathrm{MoS}_{2}\right)$ in aqueous fluids at 600-800 ${ }^{\circ} \mathrm{C}, 200 \mathrm{MPa}$ : A synthetic fluid inclusion study. Geochimica et Cosmochimica Acta 77: 175-185 
FIGURE CAPTIONS

FIGURE FOR ICON ON THE TITLE PAGE An aqueous fluid inclusion from an orogenic gold deposit observed in the crosshairs of the GeoLas $193 \mathrm{~nm}$ laser-ablation system at the University of Helsinki.

FIgURE 1 Time-resolved transient LA-ICP-MS signals of a single fluid inclusion, comparing (A) selected data collected simultaneously for all masses between ${ }^{23} \mathrm{Na}$ and ${ }^{238} \mathrm{U}$ using the new Time-of-Flight ICP-MS of TOFWERK GmbH (Thun) with (B) a synthetic signal simulating the acquisition of all 24 elements detected in this fluid inclusion by TOF, but using the typical time resolution of sequential scanning by Quadrupole ICP-MS. To achieve quantifiable signals by Laser-Ablation Quadrupole ICP-MS, inclusion analysts are forced to restrict acquisition to fewer elements, typically 6 to 12 elements only.

FIGURE 2 Range of B concentrations in different types of crustal fluids, including granitehosted hydrothermal veins and pegmatites, porphyry-copper deposits, metamorphic fluids and unconformity-related $\mathrm{Pb}-\mathrm{Zn}, \mathrm{Cu}$ and $\mathrm{U}$ deposits. References of data sources are available online at elementsmagazine.org/supplements.

FIGURE 3 Comparison between calculated and measured concentrations of (A) S and (B) $\mathrm{Au}$ in rock-buffered metamorphic fluid inclusions in barren fissure veins from the Central Alpine metamorphic dome. Analyzed S concentrations are consistent with the predicted increase with temperature, assuming iron sulfide excess in the local host rock. Analyzed Au concentrations, however, are orders of magnitude lower than the predicted solubility of the metal, showing that these prograde metamorphic fluids 
are highly Au-undersaturated (Rauchenstein-Martinek et al. 2014). The difference between the rock-buffered solubility curves for greenschist- and amphibolite-facies fluids is the result of different whole-rock compositions for both metamorphic units.

FIgURE 4 High Au concentrations ranging from 10 to $0.1 \mathrm{ppm}$ can be sustained in lowsalinity (2-4 wt.\% $\mathrm{NaCl}$ equivalent) aqueous liquids of magmatic origin down to epithermal temperatures of about $250^{\circ} \mathrm{C}$, provided that high sulfide concentrations (1000-10000 ppm) act as the complexing agent for Au. Most fluid inclusions with reliably detected $\mathrm{Au}$ from the Alto de la Blenda vein deposit in the Farallón Negro Volcanic Complex show an excess of $\mathrm{S}$ relative to $\mathrm{Fe}$ (Márquez-Zavalía and Heinrich 2016), as predicted from thermodynamic modeling of Au solubility in lowsalinity aqueous fluids derived from magmatic vapor. Complementary $\mathrm{Fe}, \mathrm{Pb}$ and $\mathrm{Zn}$-enriched brines, likely depleted in sulfide, are preserved as residual fluids in porphyry copper deposits, including the Bajo de la Alumbrera deposit that occurs nearby in the same volcanic complex, as shown in FIG. 5.

Figure 5 Plots of the (A) $\mathrm{m}(\mathrm{Zn}) / \mathrm{m}(\mathrm{Cl})$ and $(\mathrm{B}) \mathrm{m}(\mathrm{Pb}) / \mathrm{m}(\mathrm{Cl})$ ratios as a function of temperature for different types of crustal fluids, including granite-hosted hydrothermal veins and pegmatites, porphyry-copper deposits, metamorphic fluids and unconformity-related $\mathrm{Pb}-\mathrm{Zn}, \mathrm{Cu}$ and $\mathrm{U}$ deposits. Data from various sources are compared to the temperature trend (grey shaded field) of Yardley (2005). References of data sources are available online at elementsmagazine.org/supplements.

FIGURE 6 Correlation plot of the $\mathrm{Pb}$ and $\mathrm{Zn}$ concentrations for different types of crustal fluids. All data fall approximately on a linear trend of constant $\mathrm{Pb} / \mathrm{Zn}$ ratio, suggesting that metal concentrations are largely controlled by the solubility of accessory galena and 

elementsmagazine.org/supplements.

404 
Figure for title page icon

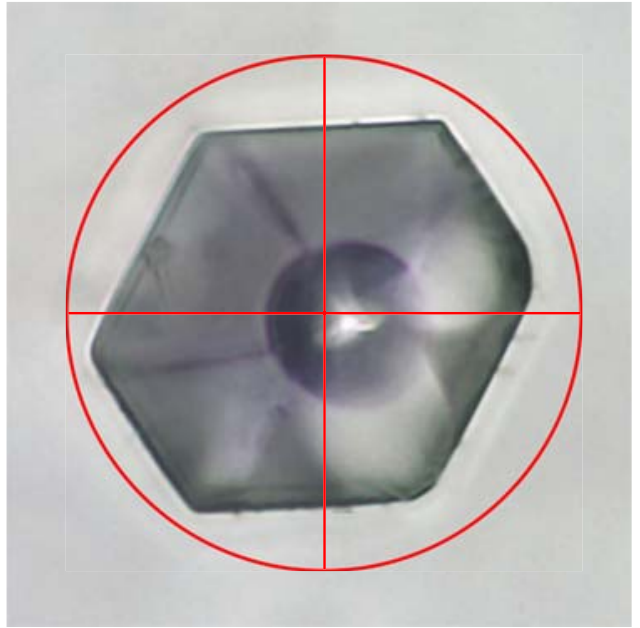


Figure 1
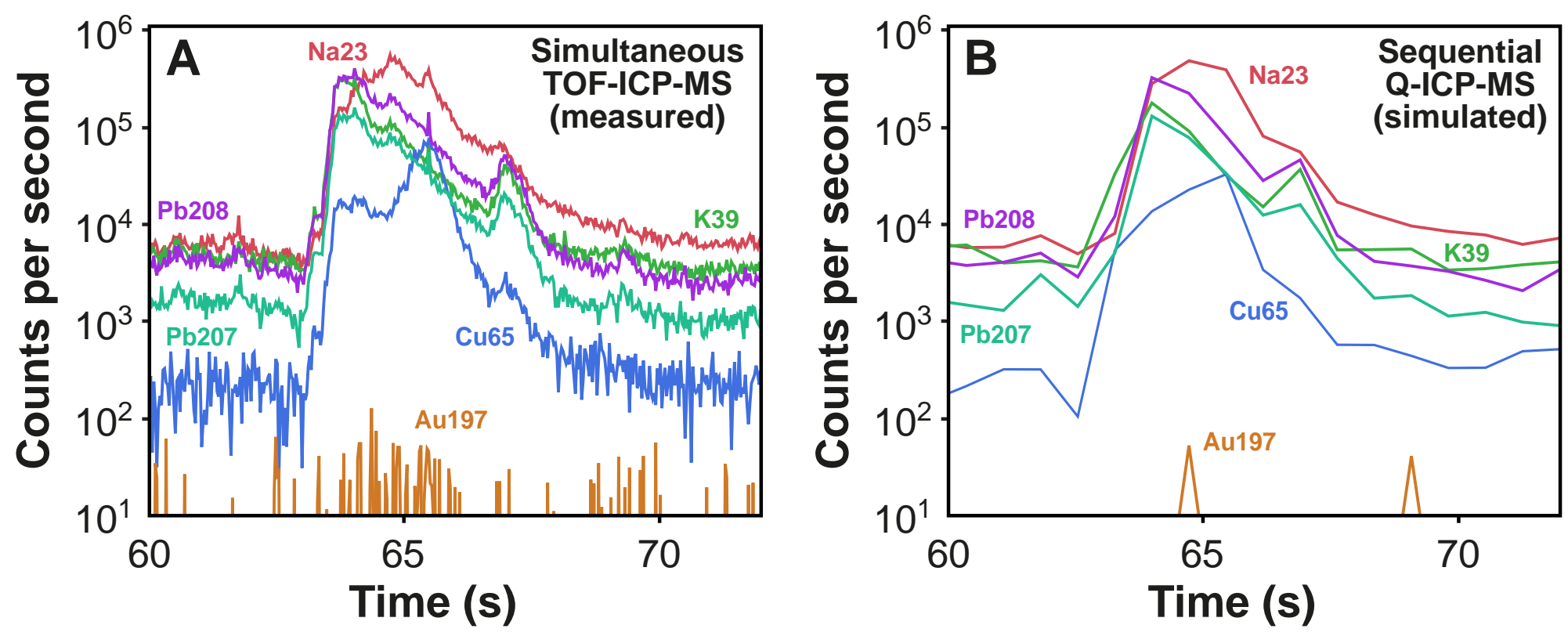
Figure 2

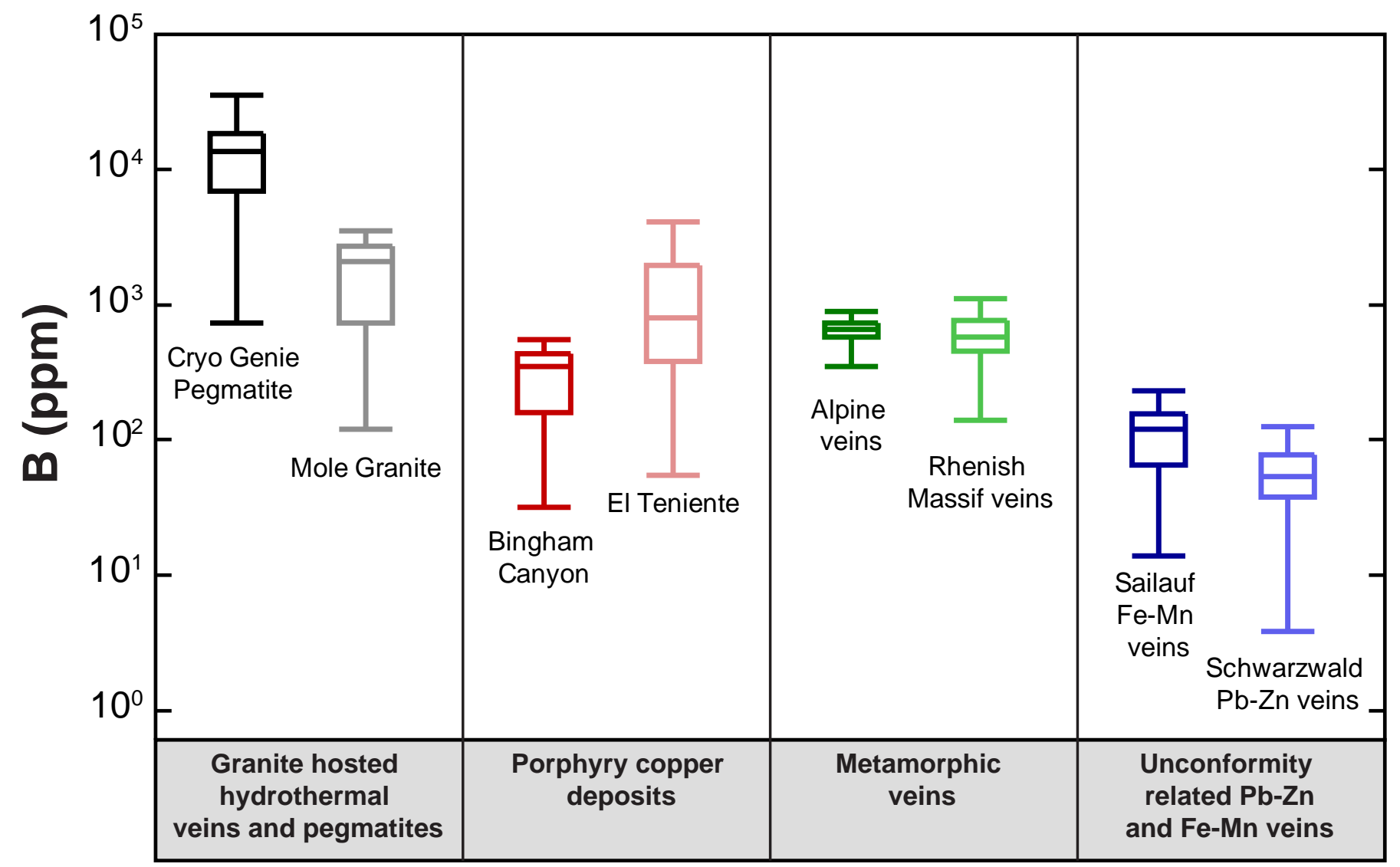


Figure 3
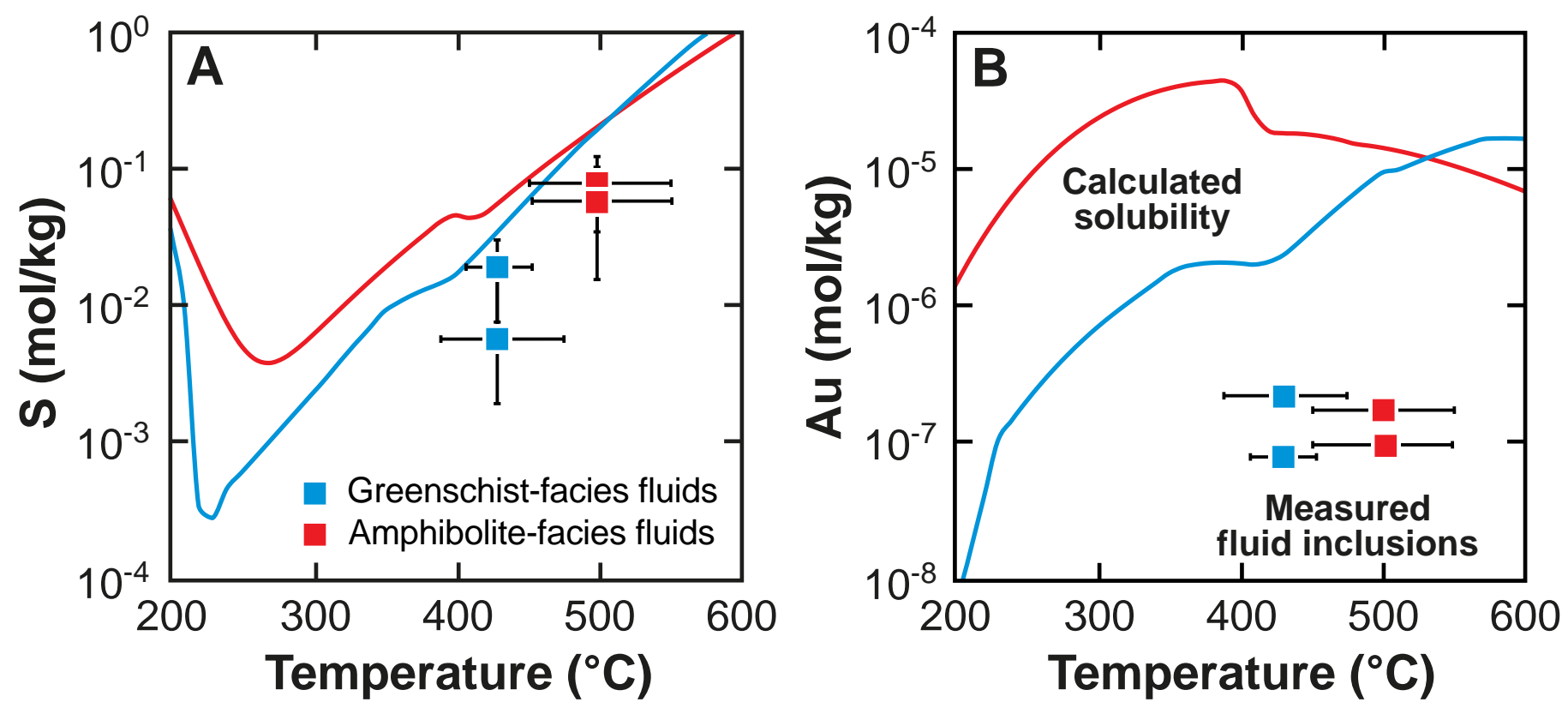
Figure 4

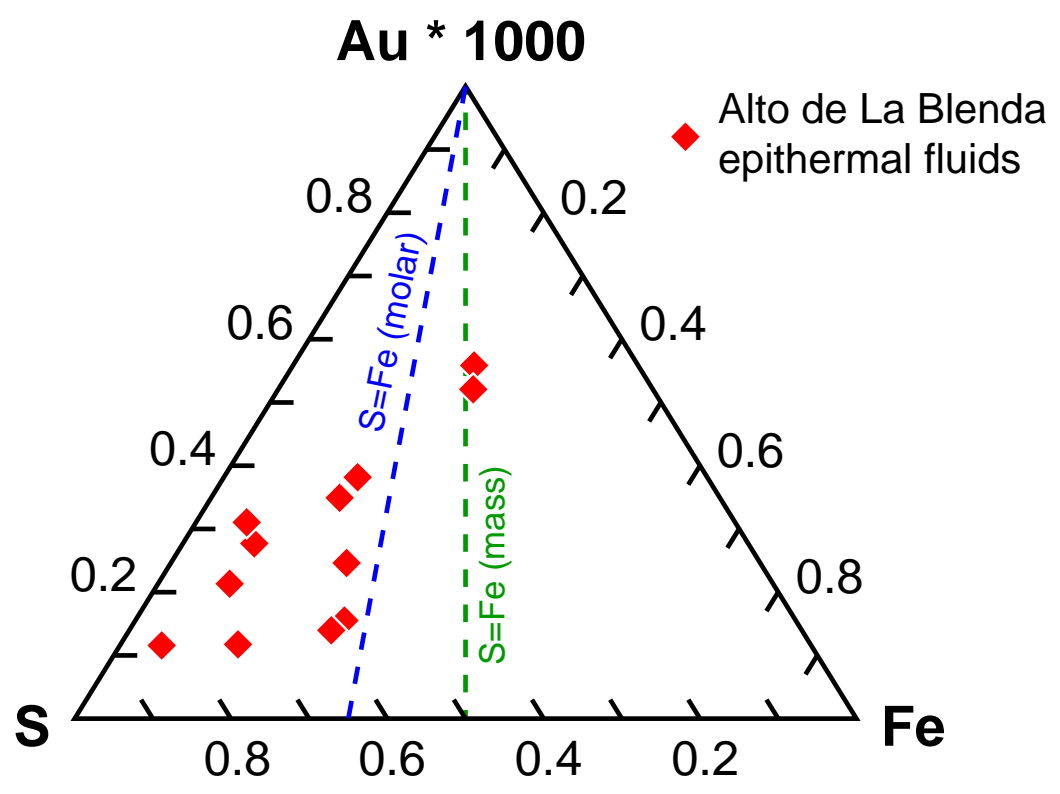


Figure 5
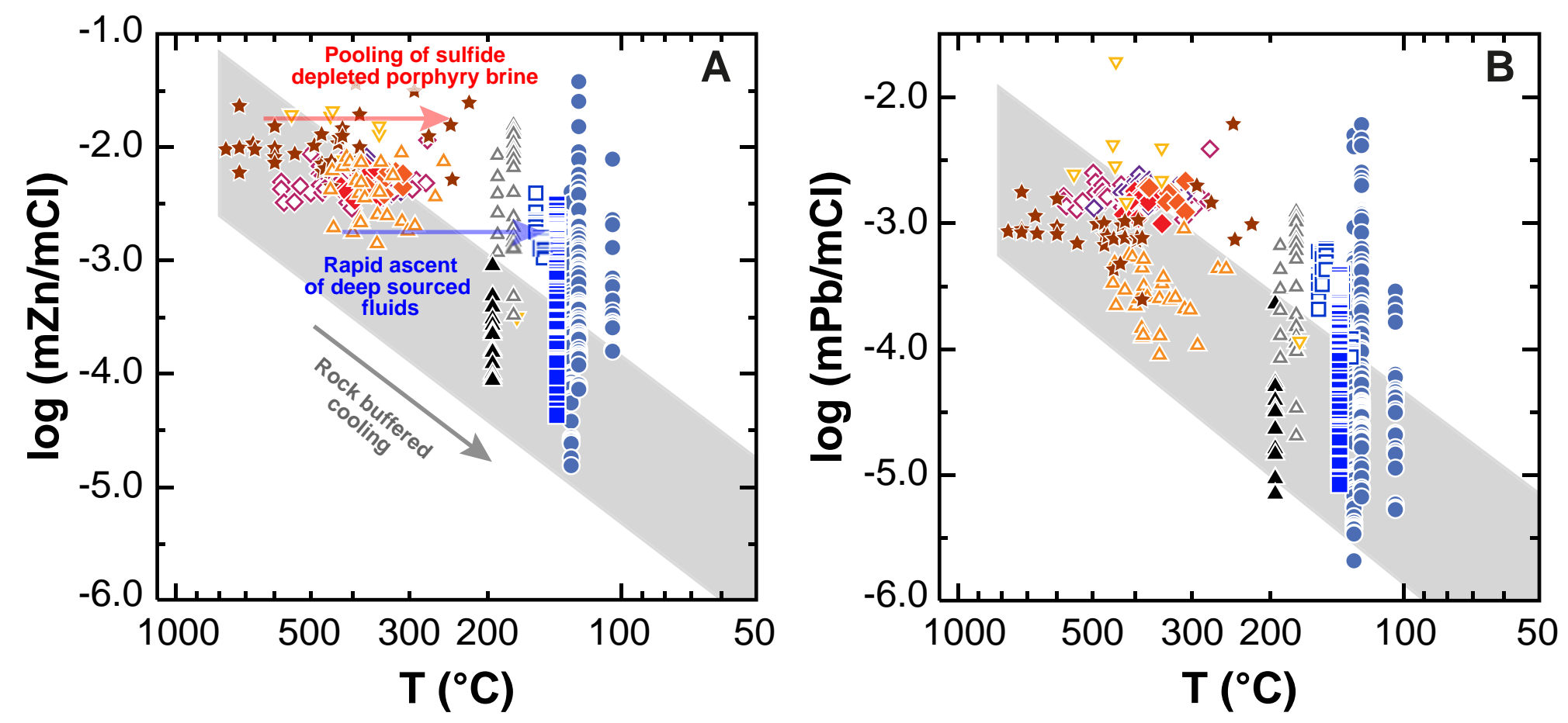

\section{Magmatic Fluids}

Bingham Canyon Cu-Au stage

Bingham Canyon late Cu-Fe stage

$\diamond$ Bingham Canyon Cu-Au stage

$\checkmark$ Bingham Canyon Mo stage

$\triangle$ El Teniente Porphyry Cu-Mo

Bajo de Alumbrera Porphyry Cu-Au

Mole Granite

\section{Basement-basin interaction fluids}

- Athabasca basin U deposits

Schwarzwald Pb-Zn vein

$\square$ Sailauf Fe-Mn veins

A Irish Midlands $\mathrm{Pb}-\mathrm{Zn}$ deposits (quartz)

$\Delta$ Irish Midlands $\mathrm{Pb}-\mathrm{Zn}$ deposits (sphalerite) ( $\mathrm{Zn}$ concentration extrapolated) 


\section{Figure 6}

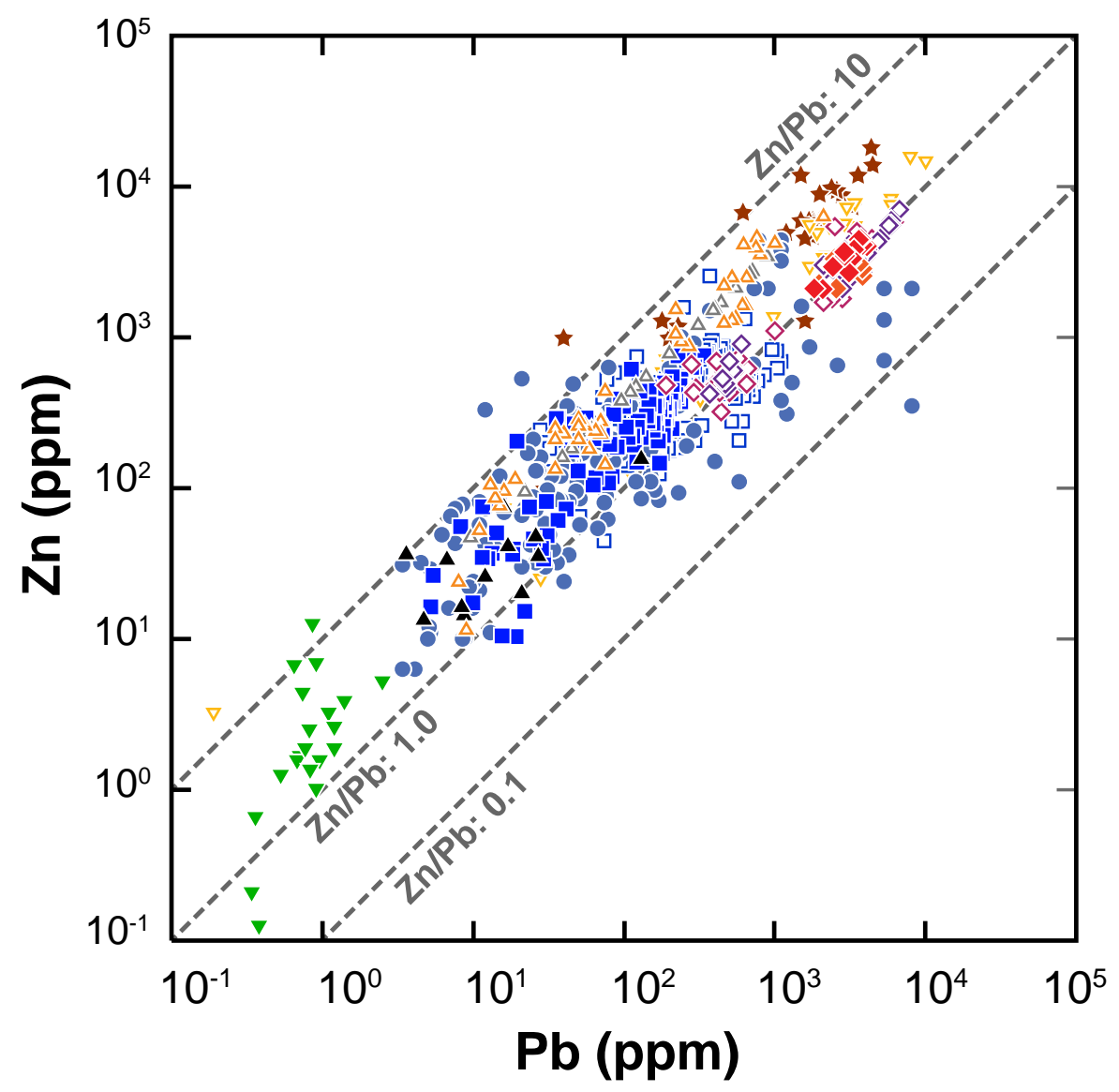

Magmatic Fluids

Bingham Canyon Cu-Au stage

Bingham Canyon late Cu-Fe stage

$\diamond$ Bingham Canyon Cu-Au stage

$\checkmark$ Bingham Canyon Mo stage

$\triangle$ El Teniente Porphyry Cu-Mo

Bajo de Alumbrera Porphyry Cu-Au

$\nabla$ Mole Granite

\section{Basement-basin interaction fluids}

Athabasca basin $U$ deposits

Schwarzwald $\mathrm{Pb}-\mathrm{Zn}$ vein

Sailauf Fe-Mn veins

$\checkmark$ Ozark Plateau MVT Pb-Zn deposits

- Irish Midlands $\mathrm{Pb}-\mathrm{Zn}$ deposits (quartz)

$\Delta$ Irish Midlands $\mathrm{Pb}-\mathrm{Zn}$ deposits (sphalerite) (Zn concentration extrapolated) 